\title{
Heterotrophic and Autotrophic Soil Respiration under Simulated Dormancy Conditions
}

\author{
Daniel Beverly ${ }^{1,2}$, Scott Franklin ${ }^{1}$ \\ ${ }^{1}$ School of Biological Sciences, University of Northern Colorado, Greeley, CO, USA \\ ${ }^{2}$ Botany Department, University of Wyoming, Laramie, WY, USA \\ Email: dbeverly@uwyo.edu
}

Received 15 February 2015; accepted 13 March 2015; published 19 March 2015

Copyright (C) 2015 by authors and Scientific Research Publishing Inc.

This work is licensed under the Creative Commons Attribution International License (CC BY). http://creativecommons.org/licenses/by/4.0/

(c) (i) Open Access

\section{Abstract}

Carbon cycling research has increased over the past 20 years, but less is known about the primary contributors to soil respiration (i.e. heterotrophic and autotrophic) under dormant conditions. It is understood that soil $\mathrm{CO}_{2}$ effluxes are significantly lower during the winter of temperate ecosystems and assumed microorganisms dominate efflux origination. We hypothesized that heterotrophic contributions would be greater than autotrophic under simulated dormancy conditions. To test this hypothesis, we designed an experiment with the following treatments: combined autotrophic heterotrophic respiration, heterotrophic respiration, autotrophic respiration, no respiration, autotrophic respiration in vermiculite, and no respiration in vermiculite. Engelmann spruce seedlings and soil substrates were placed in specially designed respiration chambers and soil $\mathrm{CO}_{2}$ efflux measurements were taken four times over the course of a month. Soil microbial densities and root volumes were measured for each chamber after day thirty-three. Seedling presence resulted in significantly higher soil $\mathrm{CO}_{2}$ efflux rates for all soil substrates. Autotrophic respiration treatments were not representative of solely autotrophic soil $\mathrm{CO}_{2}$ efflux due to soil microbial contamination of autoclaved soil substrates; however, the mean autotrophic contributions averaged less than $25 \%$ of the total soil $\mathrm{CO}_{2}$ efflux. Soil microorganism communities were likely the primary contributor to soil $\mathrm{CO}_{2}$ efflux in simulated dormant conditions, as treatments with the greatest proportions of microbial densities had the highest soil $\mathrm{CO}_{2}$ efflux rates. Although this study is not directly comparable to field dormant season soil $\mathrm{CO}_{2}$ effluxes of Engelmann spruce forest, as snowpack is not maintained throughout this experiment, relationships, and metrics from such small-scale ecosystem component processes may yield more accurate carbon budget models.

\footnotetext{
${ }^{*}$ Corresponding author.
} 


\section{Keywords}

\section{Dormant Autotrophic Respiration, Heterotrophic Respiration, Dormant Soil $\mathrm{CO}_{2}$ Efflux, Soil Respiration, Engelmann Spruce}

\section{Introduction}

Soil $\mathrm{CO}_{2}$ efflux is the primary carbon efflux from terrestrial ecosystems to the atmosphere; soils and plant biomass represent the largest terrestrial carbon pools storing more than 1000 petagrams (pg) of carbon (Bradford, Birdsey, Joyce, \& Ryan, 2008; Dixon et al., 1994; Raich \& Schlesinger, 1992). Soil $\mathrm{CO}_{2}$ efflux is composed of autotrophic (plant) and heterotrophic (microbial) metabolic processes, and is usually quantified at the soil surface as a single source flux (Amiro et al., 2010). Previous studies have attempted to separate autotrophic and heterotrophic fluxes, primarily utilizing three methods (i.e. root exclusion, component integration, and isotopic experiments) (Hanson, Edwards, Garten, \& Andrews, 2000; Lee, Nakane, Nakatsubo, \& Koizumi, 2003); however, many of these studies have limitations, as physically separating autotrophic and heterotrophic soil $\mathrm{CO}_{2}$ efflux contributions may influence available soil moisture and gas diffusion rates. Isotopic methods are a good tool for isolating heterotrophic and autotrophic respiration but are difficult to setup in situ and very costly (Coleman, 1991; Hanson et al., 2000). Thus, heterotrophic and autotrophic carbon efflux contributions to the gross soil carbon efflux are not well understood. Further, soil $\mathrm{CO}_{2}$ efflux of dormant, snow-covered forest ecosystem is a lesser studied aspect of the carbon cycle and less commonly accounted for in carbon budgets (Houghton, Hackler, \& Lawrence, 1999). Here, we attempt to separate autotrophic and heterotrophic soil $\mathrm{CO}_{2}$ efflux under simulated dormant season conditions.

Accurate quantification of carbon fluxes is necessary to construct carbon budget models and accurately estimate ecosystem productivity. Soil $\mathrm{CO}_{2}$ effluxes, as most ecosystem processes, are sensitive to seasonal and environmental change; as climates and disturbance regimes become less predictable, atmospheric carbon efflux exponentially increases driving earlier snow melt further perpetuating climate variability (Buchmann, 2000; Davidson \& Janssens, 2006; Friedlingstein et al., 2001; Stewart, Cayan, \& Dettinger, 2004). Studies during the last decade have shown that temperate ecosystems experiencing snow cover have considerably lower soil $\mathrm{CO}_{2}$ effluxes compared to growing season fluxes (Brooks, Williams, \& Schmidt, 1996; Hubbard, Ryan, Elder, \& Rhoades, 2005). Because subalpine ecosystems are typically covered with snow for longer time periods than their associated growing seasons, winter soil $\mathrm{CO}_{2}$ effluxes can compose a substantial portion of the subalpine annual carbon budget. For example, observations approximate $8 \%-15 \%$ of the annual soil $\mathrm{CO}_{2}$ efflux in subalpine forest occurs during the dormant season (Beverly, 2013; Hubbard et al. 2005). Recently, carbon cycle models have started to incorporate the contributions of winter soil $\mathrm{CO}_{2}$ efflux under snowpack (Brooks, McKnight, \& Elder, 2005), but more data and detailed knowledge from multiple ecosystems are needed.

Autotrophic respiration during the growing season results from active transport of nutrients, growth of new biomass, tissue maintenance, and exchange of allocated carbon for nitrogen between plants and heterotrophic soil microbes (Bowden, Nadelhoffer, Boone, Melillo, \& Garrison, 1993; Ryan, 1991). However, less is known about soil $\mathrm{CO}_{2}$ effluxes while many of these autotrophic processes are down-regulated during dormancy. The correlations of soil $\mathrm{CO}_{2}$ efflux with soil temperature and moisture during the growing season are well understood, making them valuable predictors for climate and ecosystem productivity models. However, for unfrozen, dormant soils, conditions are relatively stable under snowpack (Iwata, Hayashi, \& Hirota, 2008; Ryan, 1991; Sutinen, Holappa, Ritari, \& Kujala, 1999); e.g., once snowpack insulates soil, soil temperature remains approximately $0^{\circ} \mathrm{C}$ as depth of snowpack increases (Monson et al., 2006). Because of the stability of the environment under snowpack compared to the growing season, soil $\mathrm{CO}_{2}$ efflux contributions from autotrophic and heterotrophic sources may have less predictive covariables in the winter.

Separating autotrophic and heterotrophic contributions could help parameterize carbon cycle models to more accurately predict carbon fluxes under changing conditions, especially if plants and microorganisms respond differently to the changes (e.g., soil warming). However, such separation is tedious and difficult (Anderson \& Domsch, 1973; Bowden, Nadelhoffer, Boone, Melillo, \& Garrison, 1993; Hanson et al., 2000). Soil $\mathrm{CO}_{2}$ efflux quantified at the soil surface is limited to inferences on the complex microbial and root interactions occurring 
within the rhizosphere (Johnson \& Jost, 2011). The majority of data is collected from field-based experiments making accurate quantification of soil $\mathrm{CO}_{2}$ efflux contributors difficult (Hanson et al., 2000), especially with mycorrhizal symbiotic species (Paterson et al., 1997; Rouhier, Billès, Billès, \& Bottner, 1996). Bowden et al. (1993), using root and litter exclusion methods, estimated that two-thirds of summer soil respiration was contributed by root respiration; microbial soil efflux only contributed one-third from growth and decomposition.

Three techniques for quantifying autotrophic and heterotrophic contributions dominate the literature; component integration (i.e. gross flux is derived through addition of isolated contributors) (Garrett \& Cox, 1973; Johnson et al., 1994), root exclusion (Bowden, Nadelhoffer, Boone, Melillo, \& Garrison, 1993; Comstedt, Boström, \& Ekblad, 2011; Ewel, Cropper. Jr., \& Gholz, 1987), and stable and isotopic labeling (Andrews, Harrison, Matamala, \& Schlesinger, 1999; Biasi, Pitkämäki, Tavi, Koponen, \& Martikainen, 2012; Gomez-Casanovas, Matamala, Cook, \& Gonzalez-Meler, 2012) experiments. Isotopic methods require extensive sampling protocols, expensive laboratory equipment, and invasive sampling developing a below ground reference gas concentration for computing flux rates. Component integration and root exclusion methods are substantially cheaper and have been utilized in a variety of ecosystems and vegetation types; however, overestimation of soil $\mathrm{CO}_{2}$ efflux rates can occur due to soil disturbance increasing soil $\mathrm{CO}_{2}$ flushing (Hanson et al. 2000); thus, studies using these methods should be applied in experiments lasting over a week allowing for efflux rates to equilibrate. Many component integration experiments do not attempt to physically separate autotrophic and heterotrophic contributors (e.g., soil and root sterilization); rather, experiments infer that rhizosphere respiration and autotrophic respiration are not different, though heterotrophic contributions are known to be present.

In this study, we attempted to quantify soil $\mathrm{CO}_{2}$ efflux contributions of dormant Engelmann Spruce (Picea engelmannii Parry ex Engelm.) seedlings and soil microorganisms in dormant simulated conditions. We hypothesized that reduced autotrophic activity of dormant seedlings results in heterotrophic respiration composing the majority of the dormant soil $\mathrm{CO}_{2}$ efflux. To our knowledge, this is the first study trying to isolate dormant soil $\mathrm{CO}_{2}$ efflux with a controlled lab approach.

\section{Material and Methods}

\subsection{Study Design}

A chamber respiration experiment was developed using root exclusion (i.e. seedling and no seedling) and component integration (i.e. soil microorganisms and no soil microorganisms) methods for three soil types. A two factor (i.e. with and without seedling; and soil: autoclaved, non-autoclaved, and autoclaved vermiculite) study was designed for quantifying contributions of soil $\mathrm{CO}_{2}$ efflux. Factorial treatments included five replications of each treatment: autotrophic and heterotrophic respiration (AHR), autotrophic respiration (AR), heterotrophic respiration (HR), no organism respiration in soil (NR), autotrophic respiration in vermiculite (VAR), and no organism respiration in vermiculite (VNR).Vermiculite was used as an additional control (i.e. negative control) to remove soil effects on soil $\mathrm{CO}_{2}$ efflux. Seedlings were obtained from the Colorado State Forest Service Nursery (Fort Collins, CO), seedlings were grown outdoors for six months where they set bud and entered dormancy. The six treatments, of thirty chambers (15 with seedlings), were brought into the laboratory one month prior to first measurement while being stored in a cold room at $4^{\circ} \mathrm{C}$ simulating seedling dormancy and reducing metabolic activity of soil microbes. Grow lights in the cold room provided photosynthetic active radiation (PAR) of $86-102 \mu \mathrm{mol} \cdot \mathrm{m}^{-2} \cdot \mathrm{s}^{-1}$ with an 8:16 light to dark ratio mimicking winter day length. Soils for this study were collected in April 2014 from P. engelmannii stands in the Poudre Canyon approximately 60 kilometers west of Fort Collins, Colorado (N 40.637983, W 105.806136). The field site was mixed forest of P. engelmannii and Abies lasiocarpa. Snow was excavated to reach the soil surface where the top $20 \mathrm{~cm}$ of soil were collected from a $2 \times 3 \mathrm{~m}$ plot. Soils were sifted with a $2 \mathrm{~mm}$ screen producing a uniform soil substrate composed of fine sands and silts. Prior to filling soil chambers, vermiculite was thoroughly mixed with sifted soils in a 3:2 vermiculite to soil ratio to reduce soil compaction in the chambers. Soil and vermiculite substrates to be used in treatments with no heterotrophic respiration were placed in stainless steel autoclavable trays approximately $5 \mathrm{~cm}$ deep, and autoclaved three consecutive times prior to filling the soil respiration chambers (Trevors, 1996; Wolf, Dao, Scott, \& Lavy, 1989).

\subsection{Respiration Chambers}

Thirty respiration chambers were constructed from $5.08 \times 28 \mathrm{~cm}$ polyvinylchloride (PVC) plumbing pipe fitted 
with a perforated end cap (allowing for water drainage) that was sealed prior to measuring soil $\mathrm{CO}_{2}$ effluxes. Respiration chambers with seedlings had small openings $\left(1 \mathrm{~cm}^{2}\right)$ on the rim of the chamber to divert the seedling stems, and separate roots and crown mass by the chamber wall; small openings were sealed with silicone postplanting of the seedling. Respiration measurements were collected through the $81.0 \mathrm{~cm}^{2}$ opening at the top of the chamber.

Soil chambers were sterilized with $70 \%$ ethanol and then filled with 2050 cc of autoclaved soil substrate, nonautoclaved soil substrate, or autoclaved vermiculite. Seedling roots were removed of residual soil and washed; seedling root volume was measured by volume displacement in a graduated cylinder. Prior to planting, seedling roots were rinsed, surface sterilized with $70 \%$ ethanol for 30 seconds (protocol from macropropagation; Bhojwani and Razdan, 1986) then rinsed again with ultra-pure water (Milli-Q Millipore water; EMD Millipore Inc.). At the end of the experiment, seedlings were removed from chamber, cleaned, and measured for final root volumes.

Simulated winter conditions maintained an ambient air temperature of $4^{\circ} \mathrm{C}$, but initial soil moistures varied for the three soil types. Thus, chambers were watered with autoclaved water increasing soil moisture levels to field holding capacity. To ensure that seedlings were dormant, concurrent foliar gas exchange measurements were conducted on all fifteen seedlings during three of the four measurement days using a second LI6400. Measurements were conducted using the LI6400 equipped with the conifer photosynthesis chamber (Li-Cor 6400-22L); measurement conditions included PAR at $1000 \mu \mathrm{mol} \cdot \mathrm{m}^{-2} \cdot \mathrm{s}^{-1}$ and reference $\mathrm{CO}_{2}$ at $400 \mu \mathrm{mol} \cdot \mathrm{mol}^{-1}$.

\subsection{Respiration Measurements}

Soil $\mathrm{CO}_{2}$ efflux was quantified using the Li-Cor 6400 infrared gas analyzer (LI6400) (Li-Cor Inc., Lincoln NE) with a soil respiration chamber (Li-Cor 6400-09). During measurements, chambers were randomly removed from the cold room. Measurements for each chamber were conducted during the afternoon with three measurement cycles for each day of measurement; the three cycles for each chamber were averaged producing a soil $\mathrm{CO}_{2}$ efflux for each day for each chamber. Soil $\mathrm{CO}_{2}$ efflux measurements occurred two, five, ten and thirty-three days post experiment start. For analysis, soil $\mathrm{CO}_{2}$ effluxes were averaged over the four days as we did not expect, nor see, a day effect.

Soil temperature and moisture measurements were conducted with every soil $\mathrm{CO}_{2}$ efflux measurement. Soil temperatures were measured with a mercury thermometer inserted $12 \mathrm{~cm}$ into the soil column for 30 seconds. Soil moisture content was measured using HS2 Hydrosense TDR system (Campbell Scientific Inc., Logan, Utah) that averaged soil moistures from $12 \mathrm{~cm}$ to $20 \mathrm{~cm}$ in the soil column.

Soil $\mathrm{CO}_{2}$ effluxes were natural log transformed to correct for non-normality of the data. Data analysis was conducted using a forward step-wise ANOVA model with covariables of root volume, photosynthetic rate, soil moisture and temperature, bacterial and fungal densities. A two factor model, crossing of factors with autoclaved, non-autoclaved soils, and vermiculite (soil factor) with seedling or no seedling (seedling factor), was used to determine interaction effects of the treatments. Least square means with a Tukey adjustment was used as a posthoc analysis to evaluate differences among treatments. Five replications of each treatment had an $a$ posteriori ANOVA power of 0.839 .

Because root volume was a significant covariable in analysis, autotrophic soil $\mathrm{CO}_{2}$ effluxes were adjusted using root volumes for each treatment measured on day thirty-three. Adjusted soil $\mathrm{CO}_{2}$ effluxes were used to determine autotrophic contributions for each treatment.

\subsection{Microbial Quantification}

After day thirty-three, soil samples from each chamber were subjected to an eight-fold serial dilution to evaluate effectiveness of microorganism reduction within the soil substrates. The first dilution was derived from $50 \mathrm{~g}$ of soil suspended in $450 \mathrm{~mL}$ purified water. Higher dilutions were derived by adding $1 \mathrm{~mL}$ of the previous dilution to $9 \mathrm{~mL}$ purified water in a sterile $15 \mathrm{~mL}$ tube. Dilutions were thoroughly mixed with a vortex mixer before inoculating the next higher dilution. Each replicate used $100 \mu \mathrm{L}$ aliquots and a cell spreader was used to distribute aliquots evenly across selective mediums. Selective media plates were used to differentiate between fungal and bacterial soil fauna. Czapek-Dox (CZA) agars with ampicillin $(10 \mathrm{mg} / \mathrm{mL})$ plates were used to select against soil bacteria. Selection against fungal contributors was completed using nutrient agar with $0.1 \mu \mathrm{L}$ Amphotericin B. Aliquot plates for each $7^{\text {th }}$ and $8^{\text {th }}$ fold dilutions were replicated for each soil sample (6 nutrient and CZA agar 
plates per chamber). All treatments were incubated at $26^{\circ} \mathrm{C}$ for five days. Colony-forming units (CFU) were counted for both bacterial and fungal plates as an estimation of microbial density for each soil chamber (Saxena \& Stotzky, 2001). CFU counts between 3 and 300 per plate were used for analysis.

The six microbial CFU estimates (three fungal and three bacterial) for each chamber were averaged for both bacterial and fungal densities prior to analysis. Bacterial and fungal densities were used to adjust soil $\mathrm{CO}_{2}$ efflux rates to determine overall heterotrophic contributions in each soil substrate. Adjustment equations for each soil treatment (microorganism soil efflux without seedlings/total microorganisms without seedlings $=x /$ total microorganisms with seedlings) were developed to adjust soil $\mathrm{CO}_{2}$ efflux contributions.

\section{Results}

\subsection{Foliar Gas Exchange}

Foliar gas exchange measurements averaged over the three measurement days for AHR and AR suggested respiration, respectively $-2.26 \pm 1.94$ and $-1.22 \pm 1.17 \mu \mathrm{mol} \mathrm{CO} \mathrm{CO}_{2}^{-2} \cdot \mathrm{s}^{-1}$ (Figure 1). Seedlings in vermiculite soil substrates had very low photosynthetic gas exchange rates averaging $0.58 \pm 2.449 \mu \mathrm{mol} \mathrm{CO} \mathrm{Cm}^{-2} \cdot \mathrm{s}^{-1}$ (Figure 2). The high variability in foliar gas exchange resulted in no significant differences of the photosynthetic rates among the three soil substrates.

\subsection{Soil Respiration}

Soil $\mathrm{CO}_{2}$ efflux showed a significant interaction between seedling and soil substrate (Table 1). Root volume was the only significant covariable in the forward step-wise ANCOVA model (R-square $=0.32$; $p$-value $=0.029$ ); soil moisture and temperature, photosynthetic rate, and microbial densities were not significant covariables. After accounting for covariables, treatments containing a seedling had significantly higher soil $\mathrm{CO}_{2}$ efflux rates than without a seedling for all three soil types, but the proportions of autotrophic contribution to the total soil $\mathrm{CO}_{2}$ efflux was less compared to the heterotrophic contribution in autoclaved soil $(8.9 \%, p$-value $=<0.0001)$, non-autoclaved soil $(20.1 \%, p$-value $=0.0246)$, and vermiculite soil substrate $(40.1 \%, p$-value $=0.0036)$ (Figure 2 and Figure 3). The greatest soil $\mathrm{CO}_{2}$ efflux rates were in the autoclaved soil substrate with an autotrophic con-

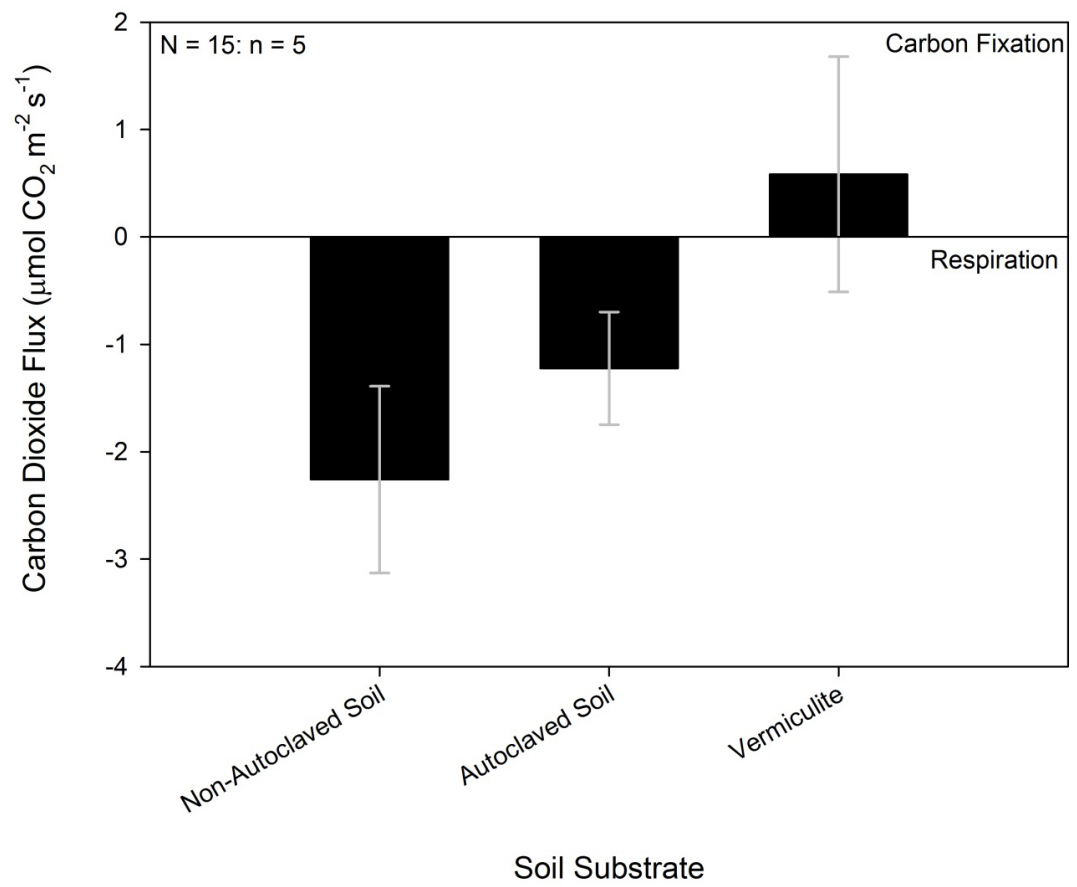

Figure 1. Foliar gas exchange rates of dormant Engelmann spruce with concurrent soil $\mathrm{CO}_{2}$ efflux measurements were not significantly different between the three soil substrates. Foliar respiration occurred in both soil treatments, but not in vermiculite. 
Table 1. Analysis of covariance examining effects of soil substrates (autoclaved, non-autoclaved, and vermiculite) and seedling (presence, absent) on soil $\mathrm{CO}_{2}$ efflux in respiration chambers under simulated dormant (winter) conditions. Covariables included root volume, photosynthetic rate, soil moisture and temperature, bacterial and fungal densities.

\begin{tabular}{|c|c|c|c|c|c|c|c|c|}
\hline Source & DF & Sum of Squares & Mean Square & Expected Mean Square & Error Term & Error DF & F Value & $p$ Value \\
\hline Tree & 1 & 0.221149 & 0.221149 & $\begin{array}{l}\text { Var (Residual) + Q (Tree, } \\
\text { Tree*Soil Substrate) }\end{array}$ & Ms (Residual) & 23 & 5.75 & 0.025 \\
\hline Soil substrate & 2 & 3.518912 & 1.759456 & $\begin{array}{c}\text { Var (Residual) + Q (Soil } \\
\text { Substrate, Tree*Soil Substrate) }\end{array}$ & Ms (Residual) & 23 & 45.76 & $<0.001$ \\
\hline $\begin{array}{l}\text { Tree*Soil } \\
\text { Substrate }\end{array}$ & 2 & 1.146466 & 0.573083 & $\begin{array}{c}\text { Var (Residual) + Q } \\
\text { (Tree*Soil Substrate) }\end{array}$ & Ms (Residual) & 23 & 14.9 & $<0.001$ \\
\hline Residual & 23 & 0.884356 & 0.03845 & Var (Residual) & & & & \\
\hline
\end{tabular}

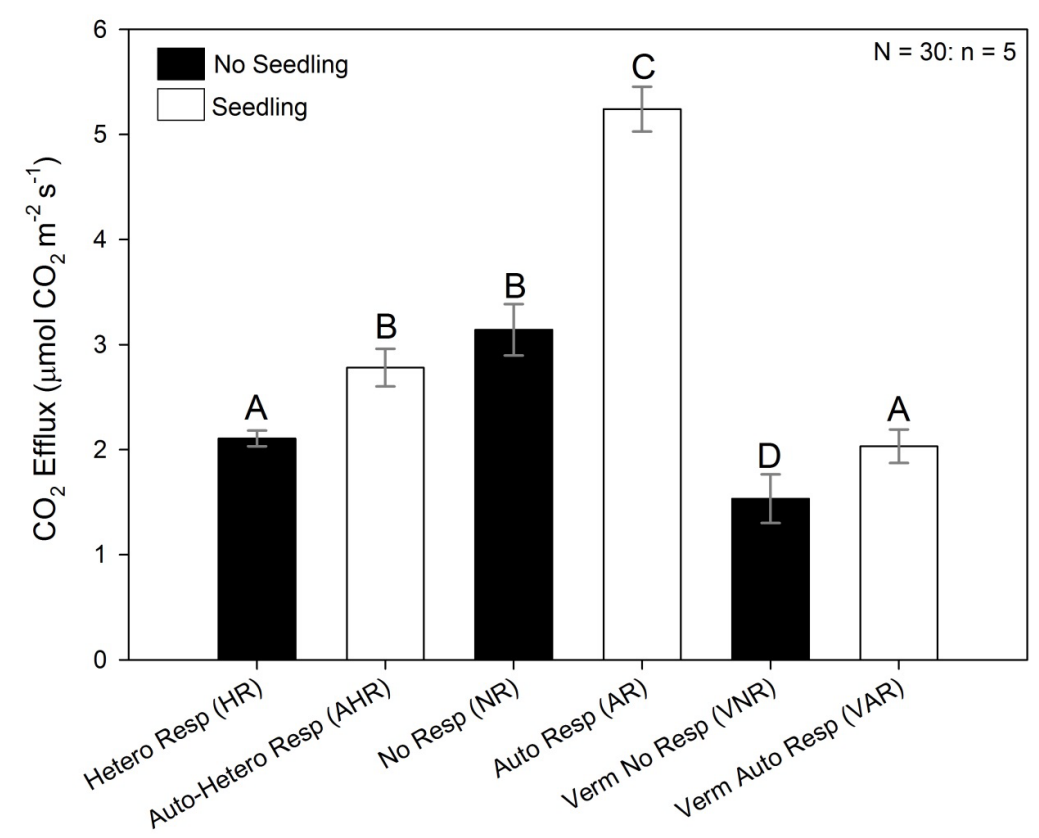

Figure 2. Soil $\mathrm{CO}_{2}$ effluxes were significantly higher with the presence of dormant seedlings independent of soil substrate. No respiration (Hobson et al.) and vermiculite no respiration (VNR) had significantly larger soil $\mathrm{CO}_{2}$ effluxes due to soil microbial contamination.

tributor (AR; $5.75 \mu \mathrm{mol} \mathrm{CO} \mathrm{Cm}^{-2} \cdot \mathrm{s}^{-1}$ ); however, this soil $\mathrm{CO}_{2}$ efflux rate included a substantial heterotrophic contribution (see microbial density results). The lowest soil $\mathrm{CO}_{2}$ efflux rates were vermiculite (VNR; $1.58 \mu \mathrm{mol}$ $\left.\mathrm{CO}_{2} \mathrm{~m}^{-2} \cdot \mathrm{s}^{-1}\right)$; which along with NR treatments produced soil $\mathrm{CO}_{2}$ effluxes due to soil microorganism contamination.

Seedling root volumes of the autoclaved soil substrate treatments were significantly larger than vermiculite and non-autoclaved soil seedlings; $28.3 \%$ and $48.3 \%$ larger, respectively (t-value $=-2.47, p$-value $=0.0296$ ) (Figure 4). Vermiculite and non-autoclaved soil substrate seedlings were not significantly different (t-value = -1.02 , $p$-value $=0.3287$ ). Root volumes consisted of less than $2 \%$ of the total chamber volume; mean root volume for all soil substrates was $1.4 \%$ of total chamber volume.

\subsection{Microbial Density}

The result of this study lasting over a month was that all treatments contained soil microorganisms; autoclaved soil substrates resulted in rapid microorganism colonization with ample nutrient availability and the absence of competitive controls for growth. Autotrophic respiration (AR) and autoclaved no respiration (NR) treatments 


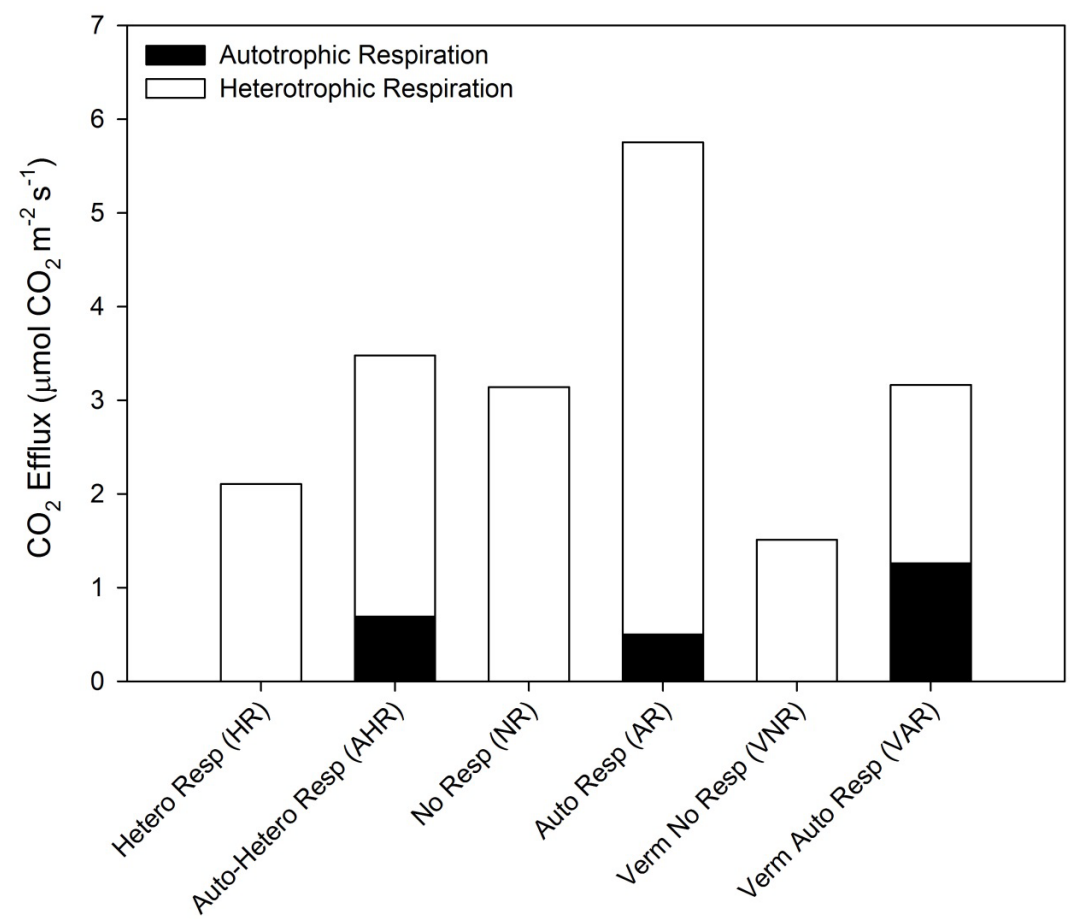

Figure 3. Adjusted soil $\mathrm{CO}_{2}$ efflux contributions for non-autoclaved soil (HR and AHR), autoclaved soil (NR and AR), and vermiculite soil substrates. Autotrophic contributions (black) were weighted on root volumes for AHR, AR, and VAR, contributing $20.1 \%, 8.9 \%$, and $40.1 \%$, respectively.

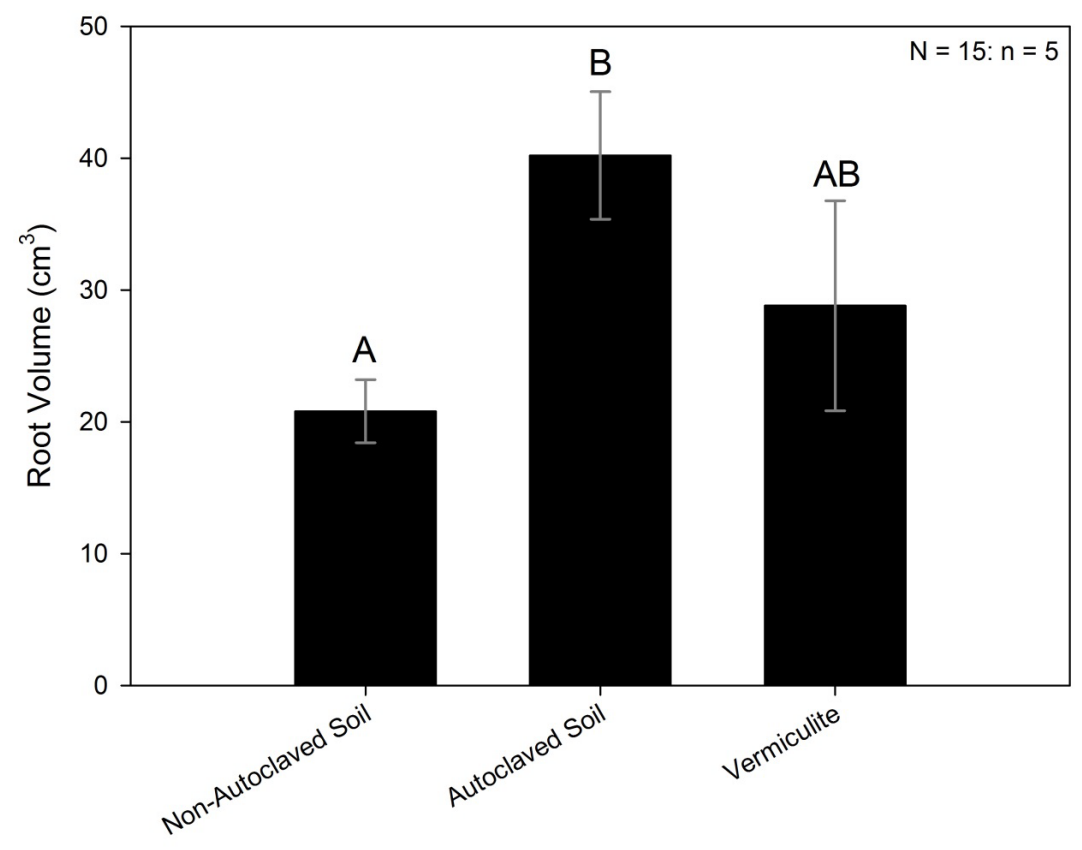

Soil Substrate

Figure 4. Root volume was the only significant variable in the global ANCOVA for predicting soil $\mathrm{CO}_{2}$ efflux. Root volumes were significantly larger in the autoclaved soil substrate than non-autoclaved soil substrate; root volumes in the vermiculite soil substrate were not significantly different from either soil substrate. 
had significantly greater densities of soil fungal growth than other treatments $(\mathrm{F}=4.17$, $p$-value $=0.0337$ ) (Figure 5). All soil substrates had substantial bacterial growth, albeit not significantly different among treatments ( $F$ $=0.15, p$-value $=0.8621$ ) (Figure 6). The greatest proportions of total soil microbial densities were in the soil chambers that had autoclaved soils and vermiculite; autotrophic treatments (AR) contained $37 \%$ of all of soil microbial biomass. Separating soil microbial groups (bacteria and fungi) shows the same trend with the autoclaved treatments containing the greatest proportions of fungal and bacterial colonization (Figure 6). Linear regression models predicting soil $\mathrm{CO}_{2}$ efflux from proportions of total soil microbial and fungal densities for all six treatments explained greater than $70 \%$ of the variability of soil $\mathrm{CO}_{2}$ effluxes; $\mathrm{R}^{2}$ values of 0.717 and 0.860 , respectively; the model for bacterial proportions explained less of the variability with an $R^{2}$ value of 0.362 .

\section{Discussion}

Contributors to soil $\mathrm{CO}_{2}$ effluxes remain poorly understood due to the difficulties of separating autotrophic and heterotrophic components; and very little is known about these contributors during the dormant season under snowpack. Temperate and subalpine forest soils are not completely frozen as snowpack insulates soil allowing for microbial and root activity (Brooks \& Williams, 1999; Hubbard et al., 2005). Winter soil $\mathrm{CO}_{2}$ efflux contributions have been estimated to be $8 \%-15 \%$ of the annual soil respiration for subalpine forests, though the organismal contribution is unknown; thus, carbon fluxes during winter conditions cannot be ignored and need to be incorporated into annual carbon budgets (Hubbard et al., 2005; Beverly, 2013), as has been shown by Wang et al. (2013).

Autotrophic respiration is the primary contributor to growing season soil $\mathrm{CO}_{2}$ efflux, accounting for twothirds of the gross soil $\mathrm{CO}_{2}$ efflux (Bowden, Nadelhoffer, Boone, Melillo, \& Garrison, 1993), but is variable and rangesbetween $10 \%$ - 90\% depending on ecosystem (Hanson et al., 2000). During our simulated dormancy, autotrophic respiration accounted for $10 \%-40 \%$ (mean $=23.0 \%$ ) of the total soil $\mathrm{CO}_{2}$ efflux, supporting our hypothesis that soil $\mathrm{CO}_{2}$ efflux in simulated dormant conditions results primarily from microbial activity (Figure 3). Engelmann spruce, as many other conifer species, are known to rapidly exit dormancy under ideal conditions leading to increased autotrophic soil $\mathrm{CO}_{2}$ efflux rates (Borken, Xu, Davidson, \& Beese, 2002); however, spruce species typically respond to increases in both light and air temperature (Granhus, FlØistad, \& SØgaard, 2009). There was potential for rapid release from dormancy during the soil $\mathrm{CO}_{2}$ efflux measurements that occurred out-

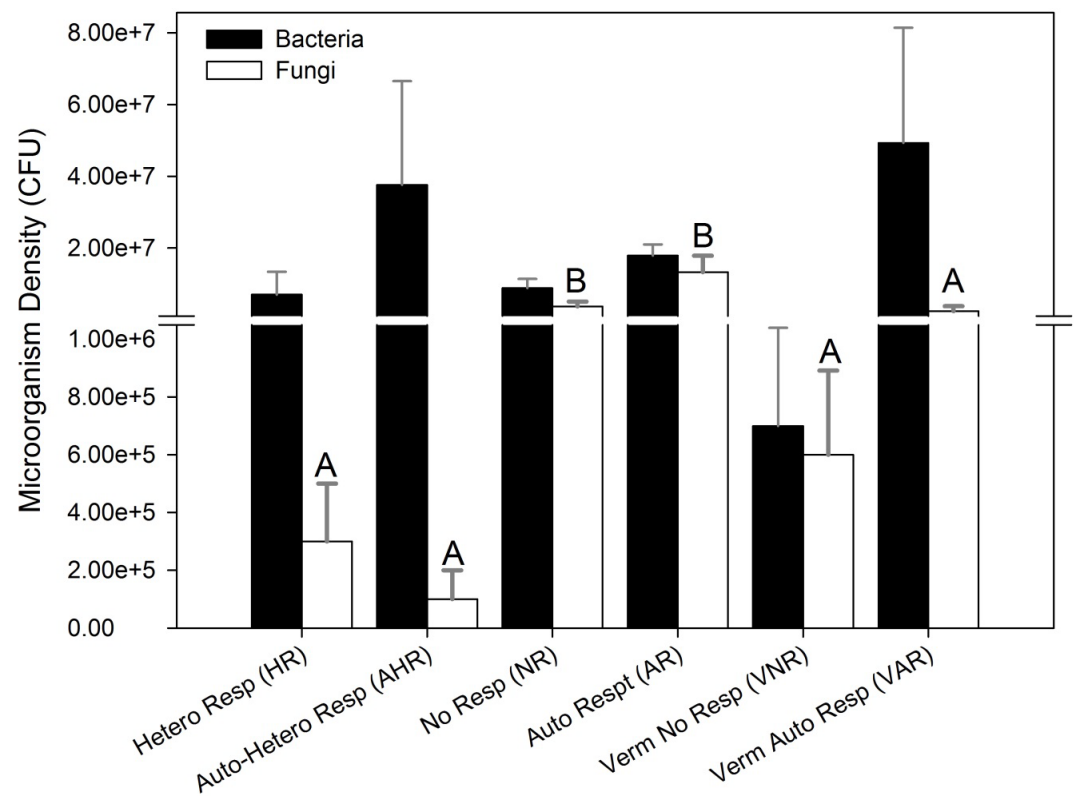

Figure 5. Soil chambers had substantial soil microbial contamination. Fungal densities of the two autoclaved soil treatments (NR and AR) had significantly higher densities compared to the vermiculite (VNR and VAR) and non-autoclaved soil substrates (HR and AHR). There were no significant differences in bacterial densities among treatments. 


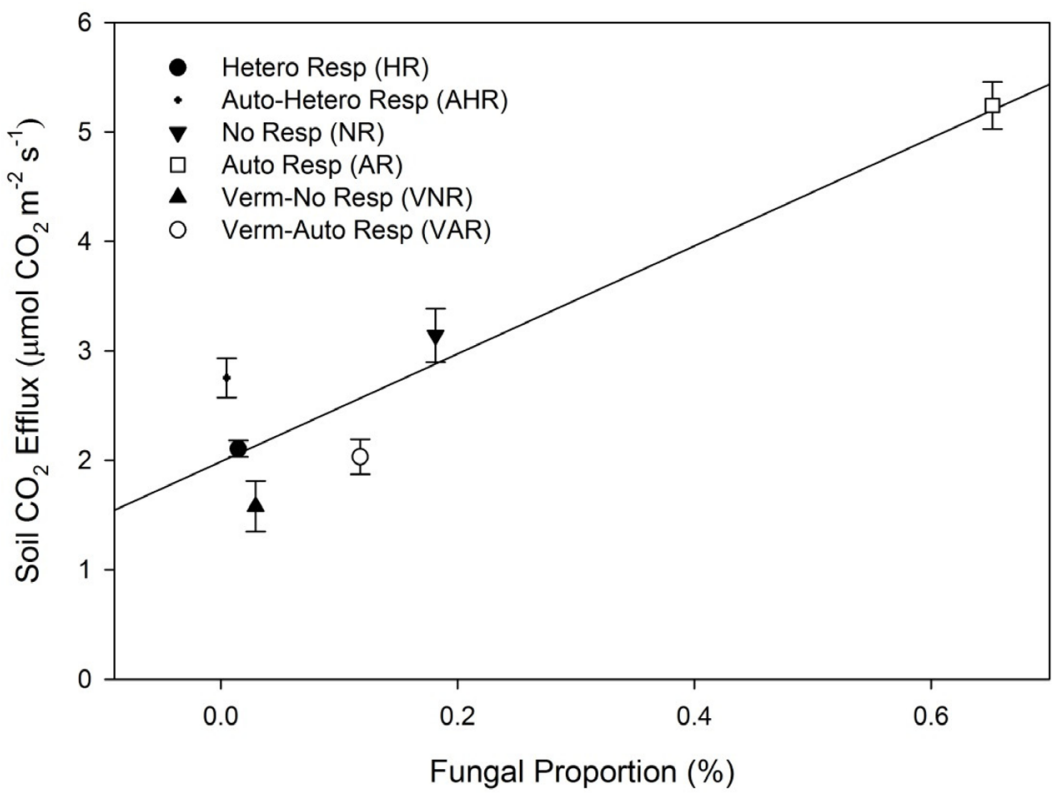

(a)

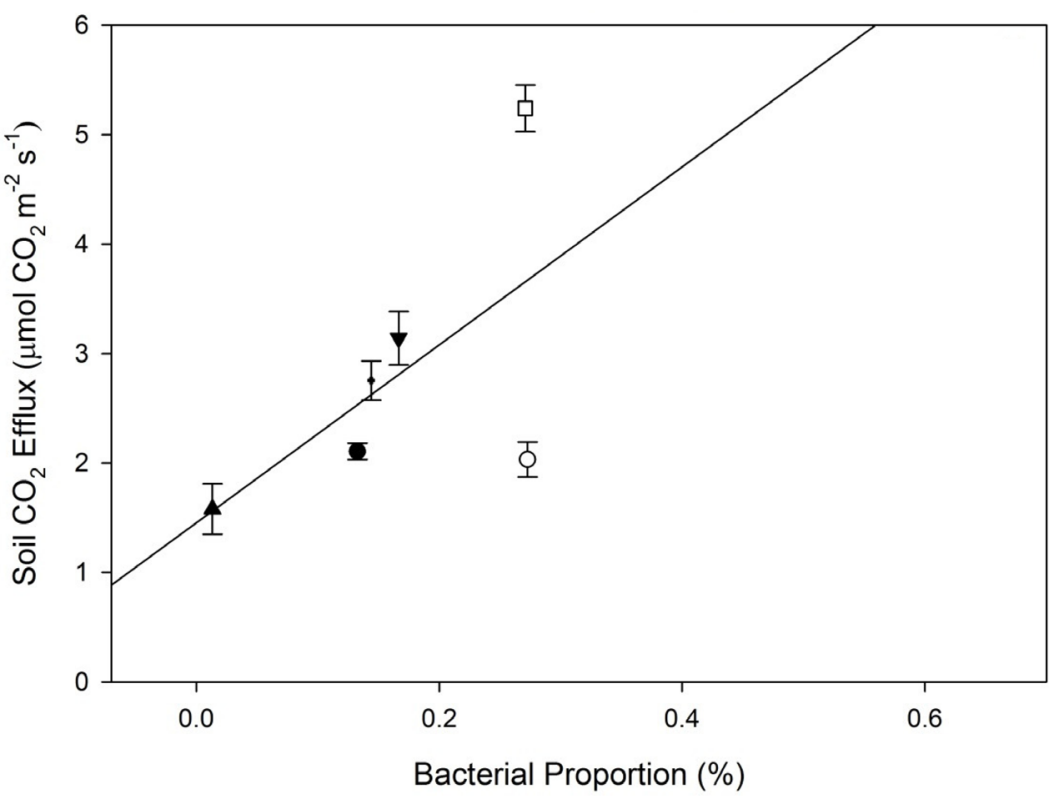

(b)

Figure 6. Soil $\mathrm{CO}_{2}$ effluxes increased with treatments containing the greatest proportions of fungi (a) and bacteria (b); $\mathrm{R}^{2}$ values of 0.86 and 0.362 , respectively. Autotrophic respiration (AR) had the greatest levels of soil microbial contamination resulting in the highest soil $\mathrm{CO}_{2}$ effluxes.

side of the cold room, but our results suggest that the duration of soil $\mathrm{CO}_{2}$ efflux measurements was too short to initiate release from dormancy. Foliar gas exchange rates suggested seedlings were dormant and carbon allocation did not occur; thus, autotrophic soil $\mathrm{CO}_{2}$ effluxes were likely a result of minimal root biomass maintenance rather than new growth or nutrient acquisition. Indeed, root biomass actually decreased over the study period (data not shown) suggesting stored carbohydrates were being catabolized. The autotrophic contribution was substantial, even with low soil $\mathrm{CO}_{2}$ efflux rates during dormant conditions, and was positively related to root biomass $\left(R^{2}=0.32\right)$ suggesting a potential metric for carbon flux models. 
Microorganism contamination of respiration chambers deserves further discussion for both the insight it gives to carbon fluxes and lessons it provides for such chamber experiments. Autoclave sterilization of soils can alter physical soil conditions, potentially affecting soil $\mathrm{CO}_{2}$ efflux (Berns et al., 2008); however, both autoclaved and non-autoclaved Douglas-fir soils from a chamber experiment similar to the present one had no significant differences in soil pH or concentrations of organic matter (Beverly, 2013). Contrarily, mineral nutrients were significantly higher in the autoclaved soils than the non-autoclaved soils; this pulse of nutrient content released into the soils was likely from microbial destruction (Alef \& Nannipieri, 1995), creating a priming effect that induced rapid fungal and bacterial growth, analogous to nutrient addition experiments that show an increase of soil $\mathrm{CO}_{2}$ efflux rates between 44\% and 169\% (Nottingham, Griffiths, Chamberlain, Stott, \& Tanner, 2009). Thus, autoclaving either did not fully sterilize soils or microbial contamination resulted following sterilization, so future studies need to sample soil microbial densities throughout the experiment. Substantial fungal contamination was a possibility due to known mycorrhizae associations with seedlings. Microbial contamination may also have occurred from the cold room ventilation systems over the course of the month during the experiment; however, contamination source needs further investigation.

We argue that the elevated soil $\mathrm{CO}_{2}$ effluxes of autotrophic only and no organism respiration treatments resulted from high levels of microorganism densities within all treatments, especially fungi. While it is impossible to determine the source of contamination, several species of mycorrhizal fungi are known to contaminate container-grown Engelmann spruce (Hunt, 1989), and substantial mycorrhizae were observed in all chambers. These results match with field data that showed peak fungal biomass was three times greater in the winter under snowpack compared to the summer growing season (Schadt, Martin, Lipson, \& Schmidt, 2003). Indeed, samples with the highest proportions of soil microbial contamination, primarily fungal contamination, yielded the largest soil $\mathrm{CO}_{2}$ efflux rates. This partially explains why the autoclaved soil substrate with seedling (AR) chambers had a heterotrophic contribution that was greater than $90 \%$ of the soil $\mathrm{CO}_{2}$ efflux (Figure 6).

While soil microorganism densities were substantially larger in the autoclaved soil substrates, densities were within known natural variation of soil microorganisms densities of pine forests (mean $=2.5 \times 10^{7} \mathrm{CFU} \mathrm{g}^{-1}$ of soil; (Moore; 1983, Vazquez et al., 1993). Fungal densities are likely the main contributor to soil $\mathrm{CO}_{2}$ effluxes under simulated dormant conditions, as fungal densities in this study were two-fold greater than natural pine forests likely increasing soil $\mathrm{CO}_{2}$ effluxes (Vázquez, Acea, \& Carballas, 1993). However, further understanding of soil microbial population dynamics of subalpine forest during dormant season is needed.

\section{Conclusion}

Our data suggest that fungal and bacterial soil communities are the major contributors to dormant season (simulated winter conditions) soil $\mathrm{CO}_{2}$ efflux, contributing approximately $75 \%$ of the total carbon efflux. This relationship is the direct inverse of summer estimates (Bowden, Nadelhoffer, Boone, Melillo, \& Garrison, 1993). Soil $\mathrm{CO}_{2}$ efflux studies from temperate ecosystems that experience extended durations of snow cover likely underestimate winter carbon budgets for several reasons. First, many long-term sampling (e.g. eddy covariance) strategies have greater error in measurements during the winter seasons (Goulden, Munger, FAN, Daube, \& Wofsy, 1996). This variability can result in a 10\% - 30\% underestimation of energy budgets, decreasing accuracy of measurements in long-term carbon budgets (Twine et al., 2000). Second, winter soil $\mathrm{CO}_{2}$ efflux is not well studied, so the knowledge of autotrophic versus heterotrophic contribution is lacking. With some uncertainties of current ecosystem models, lab and field chamber studies might be incorporated to strengthen future ecosystem flux models. For example, dormant soil $\mathrm{CO}_{2}$ efflux was positively correlated with seedling root volume $\left(\mathrm{R}^{2}=\right.$ 0.32), and such metrics may improve carbon models. In addition, seedlings significantly increased soil $\mathrm{CO}_{2}$ efflux of all three soil substrates making up the other c. $25 \%$ of winter soil respiration. While this study confirms dormant season estimates need to be incorporated into carbon budgets and ecosystem models, field comparisons are needed to develop dormant autotrophic estimates at the forest stand level. As a final note, this study suggests that autoclaving soil does not necessarily result in sterilization throughout a study and microbial densities should accompany such studies.

\section{Acknowledgements}

We would like to thank Dr. Robert Hubbard and Dr. Mitchell McGlaughlin for input and advice on the development of this project. Also, The School of Biological Sciences at the University of Northern Colorado and the 
BIOTA grant for funding this project. A special gratitude to the plant ecology class of 2013, Mario Bretfeld, Katie Whitehead, and others who contributed to on any of the five iterations of this experiment.

\section{References}

Alef, K., \& Nannipieri, P. (1995). Methods in Applied Soil Microbiology and Biochemistry. Waltham: Academic Press.

Amiro, B. D., Barr, A. G., Barr, J. G., Black, T. A., Bracho, R., Brown, M., Xiao, J. et al. (2010). Ecosystem Carbondioxide Fluxes after Disturbance in Forests of North America. Journal of Geophysical Research-Biogeosciences, 115. http://dx.doi.org/10.1029/2010JG001390

Anderson, J., \& Domsch, K. (1973). Quantification of Bacterial and Fungal Contributions to Soil Respiration. Archives of Microbiology, 93, 113-127. http://dx.doi.org/10.1007/BF00424942

Andrews, J. A., Harrison, K. G., Matamala, R., \& Schlesinger, W. H. (1999). Separation of Root Respiration from Total Soil Respiration Using Carbon-13 Labeling during Free-Air Carbon Dioxide Enrichment (FACE). Soil Science Society of America Journal, 63, 1429-1435. http://dx.doi.org/10.2136/sssaj1999.6351429x

Berns, A., Philipp, H., Narres, H. D., Burauel, P., Vereecken, H., \& Tappe, W. (2008). Effect of Gamma-Sterilization and Autoclaving on Soil Organic Matter Structure as Studied by Solid State NMR, UV and Fluorescence Spectroscopy. European Journal of Soil Science, 59, 540-550. http://dx.doi.org/10.1111/j.1365-2389.2008.01016.x

Beverly, D. M. S. (2013). Impacts of Mountain Pine Beetle and Subsequent Forest Management on Soil Carbon Dioxide Efflux. M.S. Thesis, Greeley: University of Northern Colorado.

Biasi, C., Pitkämäki, A. S., Tavi, N. M., Koponen, H. T., \& Martikainen, P. J. (2012). An Isotope Approach Based on 13C Pulse-Chase Labelling vs. the Root Trenching Method to Separate Heterotrophic and Autotrophic Respiration in Cultivated Peatlands. Boreal Environment Research, 17, 184-192.

Borken, W., Xu, Y.-J., Davidson, E. A., \& Beese, F. (2002). Site and Temporal Variation of Soil Respiration in European Beech, Norway Spruce, and Scots Pine Forests. Global Change Biology, 8, 1205-1216. http://dx.doi.org/10.1046/j.1365-2486.2002.00547.x

Bowden, R. D., Nadelhoffer, K. J., Boone, R. D., Melillo, J. M., \& Garrison, J. B. (1993). Contributions of Aboveground Litter, Belowground Litter, and Root Respiration to Total Soil Respiration in a Temperate Mixed Hardwood Forest. Canadian Journal of Forest Research, 23, 1402-1407. http://dx.doi.org/10.1139/x93-177

Bradford, J. B., Birdsey, R. A., Joyce, L. A., \& Ryan, M. G. (2008). Tree Age, Disturbance History, and Carbon Stocks and Fluxes in Subalpine Rocky Mountain Forests. Global Change Biology, 14, 2882-2897. http://dx.doi.org/10.1111/j.1365-2486.2008.01686.x

Brooks, P. D., McKnight, D., \& Elder, K. (2005). Carbon Limitation of Soil Respiration under Winter Snowpacks: Potential Feedbacks between Growing Season and Winter Carbon Fluxes. Global Change Biology, 11, 231-238. http://dx.doi.org/10.1111/j.1365-2486.2004.00877.x

Brooks, P. D., \& Williams, M. W. (1999). Snowpack Controls on Nitrogen Cycling and Export in Seasonally Snow-Covered Catchments. Hydrological Processes, 13, 2177-2190. http://dx.doi.org/10.1002/(SICI)1099-1085(199910)13:14/15<2177::AID-HYP850>3.0.CO;2-V

Brooks, P. D., Williams, M. W., \& Schmidt, S. K. (1996). Microbial Activity under Alpine Snowpacks, Niwot Ridge, Colorado. Biogeochemistry, 32, 93-113. http://dx.doi.org/10.1007/BF00000354

Buchmann, N. (2000). Biotic and Abiotic Factors Controlling Soil Respiration Rates in Picea abies Stands. Soil Biology and Biochemistry, 32, 1625-1635. http://dx.doi.org/10.1016/S0038-0717(00)00077-8

Coleman, D. C. (1991). Carbon Isotope Techniques. Amsterdam: Elsevier.

Comstedt, D., Boström, B., \& Ekblad, A. (2011). Autotrophic and Heterotrophic Soil Respiration in a Norway Spruce Forest: Estimating the Root Decomposition and Soil Moisture Effects in a Trenching Experiment. Biogeochemistry, 104, $121-132$. http://dx.doi.org/10.1007/s10533-010-9491-9

Davidson, E. A., \& Janssens, I. A. (2006). Temperature Sensitivity of Soil Carbon Decomposition and Feedbacks to Climate Change. Nature, 440, 165-173. http://dx.doi.org/10.1038/nature04514

Dixon, R. K., Solomon, A. M., Brown, S., Houghton, R. A., Trexier, M. C., \& Wisniewski, J. (1994). Carbon Pools and Flux of Global Forest Ecosystems. Science, 263, 185-190. http://dx.doi.org/10.1126/science.263.5144.185

Ewel, K. C., Cropper Jr., W. P., \& Gholz, H. L. (1987). Soil $\mathrm{CO}_{2}$ Evolution in Florida Slash Pine Plantations. II. Importance of Root Respiration. Canadian Journal of Forest Research, 17, 330-333. http://dx.doi.org/10.1139/x87-055

Friedlingstein, P., Bopp, L., Ciais, P., Dufresne, J. L., Fairhead, L., LeTreut, H. et al. (2001). Positive Feedback between Future Climate Change and the Carbon Cycle. Geophysical Research Letters, 28, 1543-1546.

http://dx.doi.org/10.1029/2000GL012015 
Garrett, H. E., \& Cox, G. S. (1973). Carbon Dioxide Evolution from the Floor of an Oak-Hickory Forest1. Soil Science Society of America Journal, 37, 641-644.

Gomez-Casanovas, N., Matamala, R., Cook, D. R., \& Gonzalez-Meler, M. A. (2012). Net Ecosystem Exchange Modifies the Relationship between the Autotrophic and Heterotrophic Components of Soil Respiration with Abiotic Factors in Prairie Grasslands. Global Change Biology, 18, 2532-2545. http://dx.doi.org/10.1111/j.1365-2486.2012.02721.x

Goulden, M. L., Munger, J. W., Fan, S. M., Daube, B. C., \& Wofsy, S. C. (1996). Measurements of Carbon Sequestration by Long-Term Eddy Covariance: Methods and a Critical Evaluation of Accuracy. Global Change Biology, 2, $169-182$. http://dx.doi.org/10.1111/j.1365-2486.1996.tb00070.x

Granhus, A., FlØistad, I. S., \& SØgaard, G. (2009). Bud Burst Timing in Picea abies Seedlings as Affected by Temperature during Dormancy Induction and Mild Spells during Chilling. Tree Physiology, 29, 497-503.

http://dx.doi.org/10.1093/treephys/tpn039

Hanson, P., Edwards, N., Garten, C., \& Andrews, J. (2000). Separating Root and Soil Microbial Contributions to Soil Respiration: A Review of Methods and Observations. Biogeochemistry, 48, 115-146. http://dx.doi.org/10.1023/A:1006244819642

Houghton, R., Hackler, J., \& Lawrence, K. (1999). The U.S. Carbon Budget: Contributions from Land-Use Change. Science, 285, 574-578. http://dx.doi.org/10.1126/science.285.5427.574

Hubbard, R. M., Ryan, M. G., Elder, K., \& Rhoades, C. C. (2005). Seasonal Patterns in Soil Surface $\mathrm{CO}_{2}$ Flux under Snow Cover in 50 and 300 Year Old Subalpine Forests. Biogeochemistry, 73, 93-107. http://dx.doi.org/10.1007/s10533-004-1990-0

Hunt, G. A. (1989). Effect of Controlled-Release Fertilizers on Growth and Mycorrhizae in Container-Grown Engelmann Spruce. Western Journal of Applied Forestry, 4, 129-131.

Iwata, Y., Hayashi, M., \& Hirota, T. (2008). Comparison of Snowmelt Infiltration under Different Soil-Freezing Conditions Influenced by Snow Cover All Rights Reserved. Vadose Zone Journal, 7, 79-86.

Johnson, M. S., \& Jost, G. (2011). Ecohydrology and Biogeochemistry of the Rhizosphere in Forested Ecosystems. In D. F. Levia, D. Carlyle-Moses, \& T. Tanaka, (Eds.), Forest Hydrology and Biogeochemistry (pp. 483-498). Berlin: Springer. http://dx.doi.org/10.1007/978-94-007-1363-5_24

Lee, M.-S., Nakane, K., Nakatsubo, T., \& Koizumi, H. (2003). Seasonal Changes in the Contribution of Root Respiration to Total Soil Respiration in a Cool-Temperate Deciduous Forest Roots. In Roots: The Dynamic Interface between Plants and the Earth (pp. 311-318). Berlin: Springer.

Monson, R. K., Lipson, D. L., Burns, S. P., Turnipseed, A. A., Delany, A. C., Williams, M. W., \& Schmidt, S. K. (2006). Winter Forest Soil Respiration Controlled by Climate and Microbial Community Composition. Nature, 439, $711-714$. http://dx.doi.org/10.1038/nature04555

Nottingham, A. T., Griffiths, H., Chamberlain, P. M., Stott, A. W., \& Tanner, E. V. (2009). Soil Priming by Sugar and LeafLitter Substrates: A Link to Microbial Groups. Applied Soil Ecology, 42, 183-190. http://dx.doi.org/10.1016/j.apsoil.2009.03.003

Paterson, E., Hall, J., Rattray, E., Griffiths, B., Ritz, K., \& Killham, K. (1997). Effect of Elevated CO $_{2}$ on Rhizosphere Carbon Flow and Soil Microbial Processes. Global Change Biology, 3, 363-377.

http://dx.doi.org/10.1046/j.1365-2486.1997.t01-1-00088.x

Raich, J., \& Schlesinger, W. H. (1992). The Global Carbon Dioxide Flux in Soil Respiration and Its Relationship to Vegetation and Climate. Tellus B, 44, 81-99. http://dx.doi.org/10.1034/j.1600-0889.1992.t01-1-00001.x

Rouhier, H., Billès, G., Billès, L., \& Bottner, P. (1996). Carbon Fluxes in the Rhizosphere of Sweet Chestnut Seedlings (Castanea sativa) Grown under Two Atmospheric $\mathrm{CO}_{2}$ Concentrations: ${ }^{14} \mathrm{C}$ Partitioning after Pulse Labelling. Plant and soil, 180, 101-111. http://dx.doi.org/10.1007/BF00015416

Ryan, M. G. (1991). Effects of Climate Change on Plant Respiration. Ecological Applications, 1, 157-167. http://dx.doi.org/10.2307/1941808

Saxena, D., \& Stotzky, G. (2001). Bacillus thuringiensis (Bt) Toxin Released from Root Exudates and Biomass of Bt Corn Has No Apparent Effect on Earthworms, Nematodes, Protozoa, Bacteria, and Fungi in Soil. Soil Biology and Biochemistry, 33, 1225-1230. http://dx.doi.org/10.1016/S0038-0717(01)00027-X

Schadt, C. W., Martin, A. P., Lipson, D. A., \& Schmidt, S. K. (2003). Seasonal Dynamics of Previously Unknown Fungal Lineages in Tundra Soils. Science, 301, 1359-1361. http://dx.doi.org/10.1126/science.1086940

Stewart, I. T., Cayan, D. R., \& Dettinger, M. D. (2004). Changes in Snowmelt Runoff Timing in Western North America under a "Business as Usual” Climate Change Scenario. Climatic Change, 62, 217-232.

http://dx.doi.org/10.1023/B:CLIM.0000013702.22656.e8

Sutinen, M. L., Holappa, T., Ritari, A., \& Kujala, K. (1999). Seasonal Changes in Soil Temperature and Snow-Cover under 
Different Simulated Winter Conditions: Comparison with Frost Hardiness of Scots Pine (Pinus sylvestris) Roots. Chemosphere-Global Change Science, 1, 485-492. http://dx.doi.org/10.1016/S1465-9972(99)00037-9

Trevors, J. T. (1996). Sterilization and Inhibition of Microbial Activity in Soil. Journal of Microbiological Methods, 26, 5359. http://dx.doi.org/10.1016/0167-7012(96)00843-3

Twine, T. E., Kustas, W., Norman, J., Cook, D., Houser, P., Meyers, T. et al. (2000). Correcting Eddy-Covariance Flux Underestimates over a Grassland. Agricultural and Forest Meteorology, 103, 279-300. http://dx.doi.org/10.1016/S0168-1923(00)00123-4

Vázquez, F. J., Acea, M. J., \& Carballas, T. (1993). Soil Microbial Populations after Wildfire. FEMS Microbiology Ecology, 13, 93-103. http://dx.doi.org/10.1111/j.1574-6941.1993.tb00055.x

Wolf, D., Dao, T., Scott, H., \& Lavy, T. (1989). Influence of Sterilization Methods on Selected Soil Microbiological, Physical, and Chemical Properties. Journal of Environmental Quality, 18, 39-44. 